\title{
The potential effect of pandan wangi leaf "pandanus amaryllifolius roxb." from indonesia as time sleep inductor
}

\author{
Nita Tri Sulistiyati, Riandini Aisyah, EM Sutrisna
}

Faculty of Medicine, University Muhammadiyah of Surakarta, Indonesia.

\section{Abstract}

Sleep plays a role in restoring the body's biochemical and physiological processes which decrease when awake. People is not familiar yet with sleep disturbances, so they rarely seek help. Sleep disturbances can cause family problems and are at risk of fatal traffic accidents. Fragant Pandan leaves (Pandanus amaryllifolius Roxb.) contains alkaloids, saponins and flavonoids which can provide a hypnotic sedative effect. The purpose of this study was to determine the effect of fragant Pandan leaf extract (Pandanus amaryllifolius Roxb.) administration in shortening the sleep induction time of male Swiss Webster strain mice. A post-test only design experimental laboratory study was conducted with control group design. The test animals used were 25 Swiss Webster male mice divided into five groups randomly : G1 group was given distilled water, G2 was given diazepam dose $1 \mathrm{mg} / \mathrm{KgBB}$, the G3, G4 and G5 groups were given fragant Pandan leaf extract with a dose of $4 \mathrm{mg} / 25 \mathrm{~g} \mathrm{BB}, 6 \mathrm{mg} / 25 \mathrm{gBB}$ and $8 \mathrm{mg} / 25 \mathrm{gBB}$, respectively. One Way ANOVA statistical test showed significant differences in mice sleep onset $(\mathrm{p}=0.000)$ between groups. The results of the Post Hoc test using LSD analysis showed that there were significant differences between positive controls with groups G3, G4 and G5. Fragrant Pandan leaf extract dose of $8 \mathrm{mg} / \mathrm{g} \mathrm{BB}$ can shorten the time of mice sleep induction male Swiss Webster strain mice. While the dose of $4 \mathrm{mg} /$ $\mathrm{g}$ BB cannot shorten the time of induction of sleeping mice.

Keywords: Fragant Pandan leaf extract; Hypnotic-sedative, Sleep disturbances.

\section{INTRODUCTION}

Insomnia is a disorder in the form of meet sleep needs inability, both quality and quantity. Data from the Diagnostic and Statistical Manual of Mental Disorder-IV, around $20-49 \%$ of the adult population in the United States have experienced symptoms of insomnia and it is estimated that $10-20 \%$ of them experience chronic insomnia. The collected data also concluded that women had a 1.5 times higher risk of experiencing insomnia compared to men [1] (Mai and Buysse, 2008). In Indonesia, the prevalence of insomnia is quite high, which is about $20-50 \%$ of elderly people experience insomnia and 17\% experience serious sleep disorders [2] (Amir, 2016). Sleep is everyone's need. Sleep gives the brain time to recover biochemical or physiological processes that progressively decrease when awake [3] (Sherwood, 2014). Some people need to sleep less than 6 hours (shortsleeper) and less than 9 hours (long-sleeper) at night to function adequately [4] . (Sadock \& Sadock, 2010).

One of the drugs used to treat insomnia is sedativehypnotic. Sedatives are drugs that can reduce anxiety and have a calming effect with little or no effect on motor or mental function. Hypnotics can cause drowsiness, prolong and maintain sleep. The ideal hypnotic should cause sleep, such as physiological sleep, and not change sleep patterns pharmacologically, cause no effects on tomorrow, rebound anxiety, or sustained sedation. The hypnotic effect can be easily obtained by increasing the

eISSN: 2523-6709

pISSN: 2523-6695

DOI: $10.31878 /$ ijcrpp.2019.34.2 dosage of sedative drugs. At even higher doses, hypnoticsedative drugs can suppress the respiratory system and vasomotor center in the medulla, leading to coma and death. Some of these classes of drugs are barbiturates and benzodiazepines. The continuous and irrational use of currently available hypnotic-sedative drugs can cause physical dependence and withdrawal symptoms [5] (Katzung, 2013).

Indonesia has abundant medicinal plants, but only $2.5 \%$ is used as traditional medicine [6]. (Khotimah, 2016). World Health Organization (WHO) recommends the use of traditional medicines in the maintenance of public health, prevention and treatment of diseases. WHO also supports efforts in improving the safety and efficacy of traditional medicines [7]. (WHO, 2016). The use of traditional medicine in general is considered safer than the use of modern medicine. This is because traditional medicines have relatively fewer side effects than modern drugs [8] (Bustanussalam, 2016). Indonesia as a tropical country has a wealth of medicinal plants. One of the plants used for traditional medicine is fragrant pandanus (Pandanus amaryllifolius Roxb). Fragant pandanus is found throughout most of Indonesia, especially in the tropics and is mostly planted in the yard or in the garden. In previous studies, it was known that fragant pandan extract at certain doses has sedative-hypnotic effects. However, evidence of the effects of fragrant pandan extract can shorten sleep induction time is not clearly known.

\section{METHODS}

Study design: This research is a laboratory experimental study with a post test only with control goup design.

Correspondence: Riandini Aisyah, Faculty of Medicine, University Muhammadiyah of Surakarta, Indonesia. E-Mail: riandini.Aisyah@ums.ac.id 
Ethical approval: This research Approved by Health Research Ethics Committee Faculty of Medicine University Muhammadiyah Surakarta in Ethical Clearance Letter No. 1195/A.1/KEOK-FKUMS/2018

Sample size: The animals used were 25 Swiss Webster male mice

Grouping: Divided into five groups randomly in each group $n=5$

Drug administration: The G1 group was given aquadest, the $\mathrm{G} 2$ group was given a dose of diazepam $1 \mathrm{mg} / \mathrm{KgBB}$, the G3, G4, and G5 group was given $4 \mathrm{mg} / \mathrm{gBB}, 6 \mathrm{mg} /$ $\mathrm{gBB}$, and $8 \mathrm{mg} / \mathrm{gBB}$ fragrant Pandan leaf extract, respectively.

Parameters studied: The onset of sleep was measured as a hypnotic-sedative effect.

Statistical analysis: The results of the study were analyzed using One Way ANOVA test with normal data distribution and homogeneous variants requirements, then continued with a Post Hoc test.

\section{RESULTS}

The hypnotic-sedative effect of fragrant Pandan leaf extract (Pandanus amaryllifolius Roxb.) on Swiss Webster strain mice shown in Table 1.

These data shown that group G5 has faster sleep onset than group G3, G4 and G1 (-), sleep onset of G4 group was faster than G3 and G1 (-), and sleep onset of group G3 was faster than G1 (-) as shown in the Table 1. These results indicate that fragrant Pandan leaf extract (Pandanus amaryllifolius Roxb) at a dose of $8 \mathrm{mg} / \mathrm{g} \mathrm{BB}$ has a faster effectiveness in inducing mice sleep time compared to a dose of $4 \mathrm{mg} / \mathrm{g} \mathrm{BB}$ and $6 \mathrm{mg} / \mathrm{g}$ BB. The results of the normality test with Saphiro Wilk and the homogenity test with Levene Test showed normal and homogeneous data distribution $(\mathrm{p}>0.005)$.

Data analysis using One Way Annova obtained $p$ value $=$

$0,000(\mathrm{p}<0.05)$ which means that there are significant differences between groups so that the hypothesis can be accepted. Post Hoc test results using the LSD (Least Significant Difference) test to find out the significant differences between groups can be seen in Table 2 .

The results of the statistical test $(\mathrm{p}<0.05)$ was proved that fragrant Pandan leaf extract (Pandanus amaryllifolius Roxb.) has an effect on the time of induction of mice sleep.

\section{DISCUSSION}

The content of fragrant Pandan leaf extract is thought to have important compounds, namely flavanoids, alkaloids and saponins. Flavanoids are a class of phenyl propanoid compounds with a carbon frame C6-C3-C6. It is nonpolar but has a sugar group which causes flavanoids to dissolve in polar solvents [9]. (Fidiyani et al., 2015). Flavanoids have a sedative effect mediated by GABA ionotropic specifically through benzodiazepine binding sites [10] (Hanrahan et al., 2011). The amentoflavone component of the flavanoids can modulate the GABA-A receptor and show high affinity for the benzodiazepine binding site [11] (Wasowski \& Marder, 2012). Since the bezodiazepine binding site is bound, the GABA-A receptor will be mediated and active so that the chloride canal is opened which causes hyperpolarization and the effect is drowsiness to sleep [10]

Alkaloids can induce sedative effects by binding directly to GABA-A receptors. (S) -reticuline acts as a positive allosteric modulator in $\alpha 3, \alpha 5$, and $\alpha 6$ isoforms of GABAA receptors. When GABA-A ionotropic receptors are bound there will be cell hyperpolarization resulting in a reduction in action potential where it will provide a hypnotic-sedative effect [12,13] (Feducuro, 2015; Ikawati, 2006). Saponins are polar compounds that bind to GABA-A receptors. The bond causes the chloride canal to open and hyperpolarization occurs and decreases excitation, causing drowsiness even to sleep [9, 14,15], (Purnomo, 2004; Shalabi \& Sana, 2012; Fidiyani et.al, 2015).

Table 1. Sleep onset of mice in each group (minutes)

\begin{tabular}{|c|c|c|c|c|c|}
\hline No & $\begin{array}{l}\text { G1(-) } \\
\text { Aquadest }\end{array}$ & $\begin{array}{l}\text { G2(+) } \\
\text { Diazepam }\end{array}$ & $\begin{array}{l}\text { G3 } \\
4 \mathrm{mg} / \mathrm{gBB}\end{array}$ & $\begin{array}{l}\text { G4 } \\
\text { 6mg/gBB }\end{array}$ & $\begin{array}{l}\text { G5 } \\
8 \mathrm{mg} / \mathrm{gBB}\end{array}$ \\
\hline$\overline{1}$ & 80 & 23 & 65 & 45 & 42 \\
\hline 2 & 106 & 18 & 79 & 40 & 39 \\
\hline 3 & 100 & 23 & 68 & 48 & 40 \\
\hline 4 & 115 & 30 & 60 & 47 & 40 \\
\hline 5 & 109 & 29 & 58 & 51 & 38 \\
\hline & 102 & 24,6 & 66 & 46,2 & 39,8 \\
\hline
\end{tabular}

Table 2. Least Significant Difference (LSD) on mice sleep onset

\begin{tabular}{lll}
\hline Group & p value & \\
\hline G1(-) - G2(+) & 0.000 & different significantly \\
G1(-) - G3 & 0.000 & different significantly \\
G1(-) - G4 & 0.000 & different significantly \\
G1(-) - G5 & 0.000 & different significantly \\
G2(+)-G3 & 0.000 & different significantly \\
G2 $(+)-$ G4 & 0.000 & different significantly \\
G2 $(+)-$ G5 & 0.005 & different significantly \\
G3 - G4 & 0.001 & different significantly \\
G3 - G5 & 0.000 & different significantly \\
G4 - G5 & 0,201 & not different \\
\hline
\end{tabular}

$(\mathrm{p}<0.05=$ different significantly; $\mathrm{p}>0.05=$ not different $)$

Int. J. Curr. Res. Physiol. Pharmacol. 2019;3(4):5-7. 


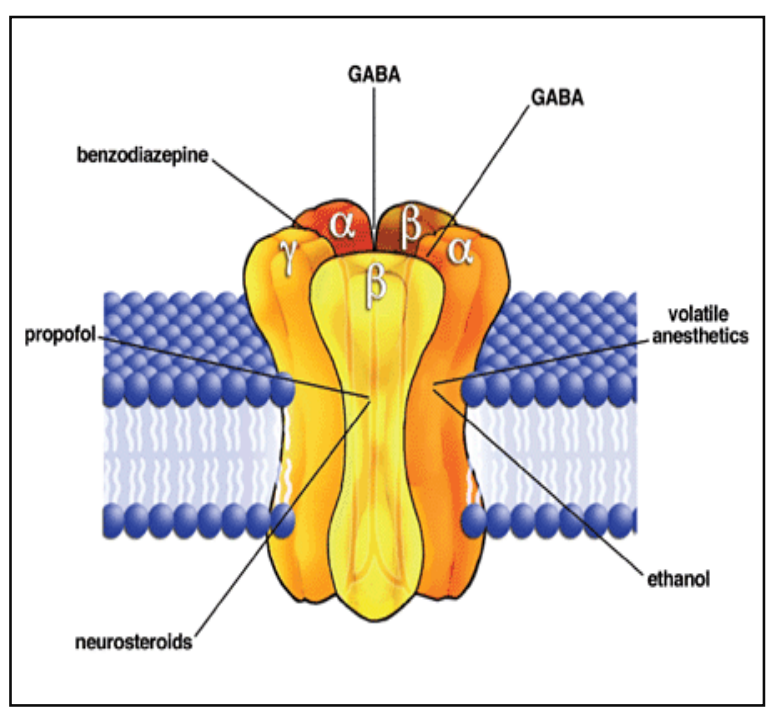

Fig 1. GABA receptor [16] (Lovinger, 2008)

Gamma-aminobutyric acid (GABA) is an amino acid that functions as the main neurotransmitter inhibitor in the central nervous system (CNS). Nearly $40 \%$ of synapses in the central nervous system are GABA neurotransmitters, and GABA-A receptors can be found almost throughout the surface of the brain [17] (Mohler, 2001). GABA has several types of receptors, namely, GABA-A, GABA-B and GABA A-rho or previously known as GABA-C [18]. (Olsen \& Sieghart, 2008). When the GABA-A receptor is activated, there will be a hyperpolarizing effect of neurons and result in a reduction in action potential. GABA receptors, some of their allosterics and GABA-A receptor subtypes are the main targets of analgesic, anxyiolitic and sedative drugs [19] (Ramachandran \& Shekhar, 2011). Activation of the GABA receptor has caused central nervous system depression effects such as sedative, hypnotic and anticonvulsant effects [13, 20] (Bateson, 2004; Ikawati, 2006). Sedation is a resting state, and hypnotics is a continuation of sedation, namely the onset of drowsiness and causes the onset of natural sleep [21] (Grace, 2007). Judging from the daily life of sleep can be influenced by environmental health status, psychological stress, diet, lifestyle and drugs [22] (Asmadi, 2008).

\section{CONCLUSION}

Fragrant Pandan leaf extract (Pandanus amaryllifolius Roxb.) dose of $8 \mathrm{mg} / \mathrm{gBB}$ and $6 \mathrm{mg} / \mathrm{g}$ BB can shorten the sleep induction time of Swiss Webster strain mice, while a dose of $4 \mathrm{mg} / \mathrm{g} \mathrm{BB}$ cannot shorten sleep induction time.

\section{REFERENCES}

[1] Mai, E., and Buysse, D.J. 2008. Insomnia: Prevalence, Impact, Pathogenesis, Differential Diagnosis, and Evaluation. Sleep Med Clin, 3(2), p.167-174.

[2] Amir, N. 2016. Sleep Disorders in Elderly Diagnosis and Management. $C D K, 157$, pp. 196206.

[3] Sherwood. L., 2014. Human Physiology from Cell to System. Issue 6. Jakarta : EGC., pp. 183-85

[4] Sadock, B.J dan Sadock,V. A. 2010. Kaplan Sadock Clinical Psychiatric Textbook. Issue 2.
Jakarta: EGC, p.339

[5] Katzung, B.G., Masters, SB., Trevor, AJ. 2013. Basic Pharmacology and Clinics, Volume I, Issue 12. Jakarta : Salemba Medika, pp. 415-21

[6] Khotimah. K., 2016. Phytochemical Screening and Identification of Secondary Metabolites Karpain Compounds on Carica Pubescens Lenne \& K. Koch Leaf Extract with LC / MS (Liquid Chromatogaph-Tendem Mass Spectometry). Malang : UIN Maulana Malik Ibrahim. Thesis.

[7] World Health Organization (WHO). 2016

[8] Bustanussalam, 2016. Utilization of Traditional Medicine (Herbs) as an Alternative Medicine. BioTrends, 7(1), pp.20-25.

[9] Fidiyani. F., Agistini. T W., Ma'ruf. W. F., 2015. Bioactive Compound Extract as a Natural Antioxidant for Fresh Spirulina plantesis with Different Solvents. JPHPI. 18(1), pp. 32-3

[10] Hanraham, J. R., Chebib, M. dan Johnston, G. A. R. 2011. Flavanoid Modulation of GABAA receptors. $B J B, 163(2)$, pp. 234-35

[11] Wasowski, C. Dan Marder, M. 2012. Flavanoids as GABAA receptor ligands: the whole story. $J$ Exp Pharmacol, 4, pp. 10. 13.

[12] Fedurco, M., Gregorova, J., Sebrlova, K., Kantorova, J., Pes, O., Baur, R., Sigel, E., Taborska, E. 2015. Modulatory Effects of Eschscholzia californica Alkaloids on Recombinant GABA-A Receptors. Biochem Res Int. p.1.

[13] Ikawati, Z. 2006. Itroduction to Molecular Pharmacology. Issue 1. Yogyakarta : UGM Press, pp. 54-6.

[14] Purnomo, L., Darsono, L., Santosa S. 2004. Effectiveness of Ules Infusa (Helicteres isora L) as a Sedative Hypnotic Drug. JKM, 3(2), p. 103

[15] Shalaby. E. A., Sanaa. M. M. S. 2012. Comparison of DPPH and ABTS Assays for Determining Antioxidant Potential of Water and Methanol Extracts of Spirulina plantesis. Indian Journal of Geomarine Sciences. 42(5)., pp. 556-64

[16] Lovinger, D.M., 2008. National Institute on Alcohol Abuse and Alcoholism. Communication Networks , pp.196-214.

[17] Mohler, H., Crestani, F. \& Rudolph, U., 2001. GABAA-receptor subtypes: a new pharmacology. Current Opinion in Pharmacology.

[18] Olsen RW, Sieghart W. 2008. International Union of Pharmacology. Subtypes of $\gamma$-aminobutyric acidA receptors: classification on the basis of subunit composition, pharmacology, and function. Update. Pharmacol Rev in Press.

[19] Ramachandran, P.V. \& Shekhar, A., 2011. Welcome to 'GABAergic drugs'. Future Med. Chem., p.139.

[20] Bateson, Alan N. 2004. The Benzodiazepine site of the GABAA receptor: an old target with new potential?. Sleep Medicine 5 Suppl, 1, p. 9.

[21] Grace, Pierce A, Borley, Neil R. 2007. At a Glance Ilmu Bedah. Edisi 3. Jakarta: Erlangga. P.69

[22] Asmadi, N.D. Nursing Procedural Techniques: Concepts and Application of Client's Basic Needs. Jakarta: Salemba Medika. pp.138-39. 